\title{
Contributions of Bioethics to Health Sector Leadership
}

\author{
Ricardo Hodelín MD MS PhD, Damaris Fuentes MD MS
}

\begin{abstract}
Leadership is the perception or acceptance by members of a group of their superior's ability to inspire, influence and motivate them to meet their goals and contribute to the achievement of shared objectives.

This article analyzes the characteristics of bioethics and the profile of the bioethicist in relation to the comprehensive development required of health leaders. We address this relationship in the areas of research and clinical practice; intersectoral activity; health sciences education; bioethicist's profile; and influence on organizational structures, functioning and decisionmaking, with particular reference to development and current situation of these aspects in Cuba.
\end{abstract}

KEYWORDS Bioethics, leadership, medical education, health professional education, health, values, workplace stress, Cuba

\section{INTRODUCTION}

Bioethics is a way of thinking that embraces the human factor as the core value, a system of reflection based on guides that promote the ability of human beings to reach their full potential. The term was coined by Van Rensselaer Potter, who defined it as knowing how to use knowledge for human survival and to improve the human condition; that is, a new scientific ethic that combines humility, responsibility, and competency-interdisciplinary and intercultural; and deepens the sense of humanity.[1] The Encyclopedia of Bioethics defines it as the systematic study of human behavior in the life sciences and health care, examining such behavior in light of moral values and principles.[2] In the second edition of his encyclopedia, Reich amended his definition, considering bioethics an applied ethics.[3]

In contrast, Garrafa and Porto put forward a bioethics of intervention, breaking with prevailing paradigms and reviving utilitarianism focused on social equity, capable of eliminating the structural divide between the world's center and the periphery, aimed at human fulfillment and overcoming inequalities.[4] In Cuba, Fung considers bioethics a new kind of knowledge requiring new terminology and increasingly sophisticated methods to reveal its micro- and macrocomplexities. In this epistemological stage, she says, bioethics tends to revolutionize conventional science and unify traditional knowledge, procedures and ethical axiology, a confluence in which global and sustainable bioethical knowledge is born.[5]

Santos has suggested the need for a more encompassing definition: bioethics as the discipline concerned with study and reflection on the dimension and the humanistic and ethical implications of advances in the sciences and health professions, as well as in health care and environmental policies. Moreover, he considers it a methodology for finding rational solutions to ethical dilemmas arising from decisions and actions in scientific and clinical settings, at both individual and social levels.[6]

Bioethics embraces philosophical analysis as a method of inquiry, while using data from sociology, economics, law, theology, history and cultural anthropology to explore different contexts. Its reflective approach, beginning at the micro level of the doctor-patient relationship and projecting to the macro level of public policies in health care and promotion of scientific research, has made bioethics a bridge of understanding between individual needs and collective responsibilities.[6] Among the broad areas of bioethics application, we are convinced the discipline has much to contribute to leadership training in the health context.

In fact, Potter's later writing emphasized that leaders must have a humane, all-encompassing bioethics geared to bioethical sustainability over the long term.[7] In our opinion, health leaders working in different areas must have comprehensive training that prepares them for conflict analysis and resolution, interdisciplinary work and consensus-building. It is precisely through study of bioethics that these and other skills can be acquired. While bioethics is not the only discipline that contributes to developing such attributes, its systematic study in constant connection with practice facilitates their integration in leadership roles.

In this article we analyze the characteristics of bioethics and the profile of the bioethicist in intimate relationship with the comprehensive development required for leaders in the health field, with particular reference to the Cuban experience. We underscore the importance of leadership in understanding work and organizational behavior, as well as the need for charismatic, transformational leadership that propels organizations toward achievement of their goals and mission.

\section{BIOETHICS, LEADERSHIP AND HEALTH}

Many definitions of leadership have been put forward, some focusing on performance of prescribed roles in formal organizational structures.[8] Here we concentrate on its psychosocial dimensions, in concurrence with Casales' definition of leadership as the group perception or acceptance of its head's capacity to inspire, influence and motivate its members to reach certain goals while simultaneously making an important contribution of his or her own to achieving shared objectives. By this definition, genuine leaders must enjoy real support and uncoerced acceptance by the members of the group they direct.[9]

As described above, bioethics is characterized by rational analysis of conflicts derived from applying science and technology as well as ethical, moral, societal and individual standards; full and appropriate use of information about the theme or case under review; interdisciplinarity; dialogue and reasoned argument; consensus seeking; and social responsibility in addressing lines of research that could prove harmful to human beings.[1]

How do these characteristics facilitate comprehensive development of leadership in the health sector? Situations arise frequently in which ethical, moral, societal and/or individual standards may be violated. Leaders must be prepared to confront such situations with convincing evidence-based arguments. Without valid 
information - that is, without in-depth knowledge of the theory and facts of the case-informed decisions cannot be reached. Yet, such decisionmaking is basic to exercising good leadership.

Research and clinical practice Leaders are required to be highly vigilant in exercising social responsibility vis-à-vis lines of research that could prove harmful to human beings: research that does not follow established guidelines, or uses inappropriate biostatistical tools, or in which ethical aspects are violated. Leadership also requires decisions concerning studies to determine their social applicability, also implying judgment on soundness of study design and its applicable ethical precepts-including the need for informed consent when human participants are involved-recalling that not everything that is technically feasible is ethical.

Leaders also must be rigorous in their application of international norms such as good clinical practice guidelines; in 1992, Cuba was the first Latin American country to adopt such standards, which were amended in 1995, and again in 2000.[10,11]

With respect to good clinical practices in general and their extension to clinical research, we can summarize by saying that these standards express a way of doing things, the adherence to international scientific and ethical quality standards in procedures for organization, implementation, oversight, data collection, documentation and validation of clinical trials; all in the name of safeguarding the rights and integrity of human subjects and ensuring quality of results and appropriateness of research.[10,11]

This is not research for research's sake or for climbing an academic ladder; the aim is to solve scientific problems with a view towards social application of solutions. The scientific literature contains persuasive examples on the importance of leadership in health research with community participation, including the work of Martínez in Cuba, who concludes that research results suffer if there is not a good relationship between researchers and community leaders.[12]

Interdisciplinary, intersectoral leadership The issue of leadership has been on the agenda of decisionmakers in health for many years. In 1986, PAHO initiated a series of meetings with the Latin American and Caribbean Public Health Education Association and the Association of Schools of Public Health of the United States to examine problems in depth related to public health practice. After six working meetings, the parties concluded that promoting leadership in health was most important, forging close ties with health services and focusing on decisionmakers, with emphasis on broader sociopolitical dialogue in an intersectoral context.[13]

As they concluded, the health sector cannot attain its goals without relating to other sectors; hence, the importance of health sector leaders' capacity for interdisciplinary and intersectoral work. This is critical in the bioethical model-which also emphasizes dialogue and consensus-building. In Cuba, two notable examples of intersectoral action applied to health problems are dengue prevention[14] and disaster preparedness.[15] Castell-Florit, who has published widely on the subject of intersectorality for improving health results in Cuba, has paid particular attention to the role of leaders in this process, analyzing the successes and weaknesses of results thus far. He observed that public health has not taken full advantage of the power of intersectoral action and that there has sometimes been a gap between leaders' theoretical knowledge and its application in practice. He also points out the importance of including leadership development in curricula for the health professions, arguing that this would not only contribute to more effective professionals but also give them important tools to help facilitate intersectoral collaboration.[16]

Bioethics, health sciences education and leadership Each leader must assume his or her respective role in developing the health system, recognizing the importance of associating leadership and sectoral management with the need for advanced academic training closely linked to the practical needs of the health sector. Health sciences students in Cuba receive such comprehensive training. Yet, bioethics only now is being gradually introduced into the various curricula. Until recently, for the most part, incorporating characteristics of the bioethicist's profile into the daily practice of future health professionals and leaders has depended upon learning from professors who provide ethical role models, and on the fact that these role models are exercised in service-learning sites.[17] While undergraduate nursing and health technology curricula have a program on professional ethics and bioethics, until now bioethics has been practically absent from undergraduate education in dentistry, psychology and medicine.

It is only fair to mention that medical ethics has been part of the medical curriculum for many years, with a special emphasis on the doctor-patient relationship. Most recently, bioethics has become part of the core curriculum in the Philosophy and Health course delivered in all health professional programs, including medicine. This has given students an opportunity to learn about new dilemmas that traditional medical ethics cannot address.

Bioethicist's profile in leadership We are persuaded that good leaders must follow bioethical principles, summed up in the bioethicist's profile. This consists of an open mind, willingness to engage in dialogue, ability to work as part of a multidisciplinary team, systematic study, a sense of social responsibility and willingness to constantly go back and begin analysis anew.[1]

The connection between this profile and good leadership is intuitive, since keeping an open mind, maintaining an ongoing dialogue with the group and working as part of a multidisciplinary team are necessary skills for success in any health work. Systematic study is fundamental: a person cannot lead if not professionally qualified, if he or she does not know what is being published in the field and does not motivate the group to conduct research with socially responsible ethical standards. When poor research procedures have been used, a leader takes the group back to the drawing board to search for better ways to obtain results.

Bioethics, leadership and organizational behavior If managers truly exercise a leadership function, they can play a key role in influencing health as well as organizational and staff behavior. Leadership in health goes beyond the simple fact of an administrative appointment; it is an attribute achieved by constant work in the supervisor-subordinate relationship, where supervisors become real leaders through thorough, conscious self-improvement that makes them stand out and be recognized by the group. $[18,19]$ In Cuba, a positive relationship between workers and their supervisors has been considered fundamental to achieving health equity.[20] Election or selection of leaders is discussed with staff, their performance is systematically analyzed, and the group's perspective can influence leadership changes. 
Lack of support from supervisors is inversely proportional to workplace wellbeing, leading to workplace stress. In fact, supervisor-subordinate relations are known to be one of the most common sources of stress in organizations.[21] In Cuba, systematic monitoring and supervisor performance evaluation are aimed at ensuring good supervisor-subordinate relations to alleviate stress. However, as a Cuban study has shown, when leaders behave poorly, the situation may become abusive and exhausting, creating a major source of stress that jeopardizes employees' health and wellbeing. The same study revealed that staff who feel their supervisors are abusive experience little work satisfaction and suffer from low morale, greater psychological distress and higher levels of work and family conflict.[21] In our opinion, employees should have a greater voice in determining organizational and institutional leadership, even in Cuba.

Bioethics, values and leadership in health In Cuba, Delgado has argued that this new knowledge of bioethics constitutes the marriage of cognition and values in scientific knowledge, in the projection of a world view from the integrated perspective of the human being inserted in a culture, not of a transcendent actor lacking in values.[22] Hierarchy and conflicting values have been the focus of attention and debate in the development of analytical and decision-making procedures contributed by bioethics, as reported by Acosta Sariego in Cuba.[23]

Any bioethics dialogue requires essential conditions such as mutual respect, tolerance, fidelity to one's own values, attentive listening, humility, and the recognition that no one has a monopoly on the truth and that we must all be receptive and prepared to see other perspectives.[1] In other words, good leadership requires us to listen to one another, enrich interdisciplinary professional com- petencies, and increase the authenticity of agreement. Scientific or spiritual dogmas and reductionist views are a real hindrance to leadership development.

Values are key elements of organizational culture and social structure, since they determine the attitudes that motivate members toward achievement of goals and objectives. Moreover, values act by influencing an organization's operational strategies and even determine organizational climate. For organization members to act in harmony and give priority to group interests, team spirit and group values are essential, and leadership is one of the most important factors in organizational value creation and transmission.[24] The role of leaders in the health-or indeed in any-sector is therefore fundamental.

Good leaders can motivate their followers to defend their values, creating a cooperative and supportive social climate that smoothes the way to meeting objectives. If they do not, they can turn into anti-leaders who engender in their subordinates hostile attitudes that slow work and hinder achievement of objectives. Consequently, personal characteristics such as leaders' values and behavior are essential to a positive workplace social climate and certainly to a motivational structure that facilitates optimal outcomes in health institutions.

\section{CONCLUSIONS}

The discipline of bioethics supports development of skills that are critical to effective leadership, which in turn is indispensable for enabling organizations to meet their goals and accomplish their missions. Hence we propose that training in bioethics be required in health professional curricula, as is being introduced in Cuba. - 1/

\section{REFERENCES}

1. Potter VR. Bioethics: Bridge to the future. Englewood Cliffs. NJ: Prentice-Hall; 1971. 205 p.

2. Reich WT, editor. Encyclopedia of bioethics. New York: The Free Press; 1978. 1033 p.

3. Reich WT, editor. Encyclopedia of Bioethics. 2nd ed. New York: MacMillan; 1995.5 vols; 2950 p.

4. Garrafa V, Porto D. Bioética, poder e injusticia: por una ética de intervención. In: Acosta Sariego JR, editor. Bioética para la sustentabilidad. Havana: Publicaciones Acuario. Centro Félix Varela; 2002. p. 185-200. Spanish.

5. Fung Riverón T. La bioética: ¿un nuevo tipo de saber? In: Acosta Sariego JR, editor. Bioética para la sustentabilidad. Havana: Publicaciones Acuario. Centro Félix Varela; 2002. p.45-54. Spanish.

6. Santos y Vargas L. La bioética como una disciplina crítica. In: Acosta Sariego JR editor. Bioética para la sustentabilidad. Havana: Publicaciones Acuario. Centro Félix Varela; 2002. p. 55-68. Spanish.

7. Potter VR. Temas bioéticos para el siglo XXI. Rev Latinoam Bioética. 2002;2:150-8. Spanish.

8. Salas Segura S, Zárate Grajales RA. Organización Panamericana de la Salud. Cooperación técnica para el desarrollo de la capacidad gerencial en enfermería. Informe final del Taller de Gerencia en Enfermería en los Servicios de Salud [Internet]. Mexico City: Pan American Health Organization; 1999 Aug [cited 2012 Jan 3]. Available from: http://www.paho.org/Spanish/ $\mathrm{HSP} / \mathrm{HSO} /$ hsonur2.pdf. Spanish.

9. Casales JC. Patrones de liderazgo, estrés y desempeño profesional en instituciones de salud [Internet]. Rev Cubana Psicol. 2000 [cited 2012 Jan 3];17(2). Available from: http://pepsic .bvsalud.org/scielo.php?pid=S0257432220000 $00200006 \&$ script $=$ sci arttext\&tlng $=e n$. Spanish

10. Arús $\mathrm{E}$, Barroso $\mathrm{MC}$, Cires $\mathrm{M}$, Fernández $\mathrm{E}$, Fors $M$, González R. Buenas prácticas clínicas en Cuba. Havana: CECMED; 2000. Spanish.

11. Regulación No. 52-2008. Requerimientos para la Certificación de Buenas Prácticas Clínicas. Havana: CECMED; 2008. Spanish.

12. Martínez Calvo $S$. La investigación comunitaria y los valores éticos. In: Acosta-Sariego, editor. Bioética desde una perspectiva cubana. 3rd ed. Havana: Publicaciones Acuario. Centro Félix Varela; 2007. p. 67-72. Spanish.

13. Ferreira JR. El liderazgo en Salud Pública en América [Internet]. Educ Méd Salud. 1989 [cited 2012 Jan 3];23(1):5-13. Available from: http:// hist.library.paho.org/Spanish/EMS/2593.pdf. Spanish.

14. Sánchez L, Pérez D, Alfonso L, Castro M, Sánchez LM, Vander Stuyft P, et al. Estrategia de educación popular para promover la participación comunitaria en le prevención del dengue en Cuba [Internet]. Rev Panam Salud Pública. 2008 [cited 2012 Apr 20];24(1):61-9. Available from: http://www.scielosp.org/pdf/rpsp/v24n1/ v24n1a08.pdf. Spanish.

15. Mesa Ridel G. Los desastres y la experiencia cubana en salud para su prevención [Internet]. Rev Cubana Med Gen Integr. 2003 [cited 2012 Jan 4];19(3). Available from: http://scielo.sld.cu/scielo.php?pid=S0864 $-21252003000300001 \&$ script=sci. Spanish.
16. Castell-Florit Serrate P. La intersectorialidad en la práctica social. Havana: Editorial Ciencias Médicas; 2007. Spanish

17. Hodelín Tablada R. La enseñanza de la bioética en el pregrado. Reflexiones sobre un problema inconcluso [Internet]. Rev Haban Ciencias Méd. 2007 [cited 2012 Jan 4];6(5). Available from: http://scielo.sld.cu/pdf/rhcm/v6s5/rhcm08507 .pdf. Spanish.

18. Barbón Pérez OG, Bustamante Alfonso LM. La superación idiomática del directivo cubano de la misión médica internacionalista desde el enfoque humanista [Internet]. Educ Méd Superior. 2011 [cited 2012 Jan 7];25(2):197-205. Available from: http://scielo.sld.cu/pdf/ems/v25n2/ems16211 .pdf. Spanish.

19. Vidal Ledo M, Hernández García L. Superación profesoral [Internet]. Educ Méd Superior. 2011 [cited 2012 Jan 7];25(2):206-16. Available from: http://scielo.sld.cu/pdf/ems/v25n2/ems 17211 .pdf. Spanish.

20. Hodelín Tablada R, Fuentes Pelier D. Acercamiento a la equidad en el sistema de salud cubano. Universidad Virtual de Salud. Línea Temática 3. Primer Coloquio de Atención Primaria de Salud y Salud Pública. II Evento Científico y 1er Coloquio Virtual de las Maestría de Atención Primaria de Salud y Salud Pública, 2011; Havana: National Medical Sciences Information Center; 2011. Spanish.

21. Peiró JM, Rodríguez I. Estrés laboral, liderazgo y salud organizacional. [Internet]. Papeles del Psicólogo. 2008 [cited 2012 Jan 3];29(1):68-82. Available from: http://www.papelesdelpsicologo .es/pdf/1540.pdf. Spanish. 
22. Delgado Díaz CJ. Hacia un nuevo saber. La bioética en la revolución contemporánea del saber. Havana: Publicaciones Acuario. Centro Félix Varela; 2007. p. 187. Spanish.

23. Acosta Sariego JR. Los árboles y el bosque. Texto y contexto bioético cubano. Havana: Publicaciones Acuario. Centro Félix Varela; 2009. p. 45. Spanish.

24. Aguilar-Luzón MC, Calvo-Salguero A, GarcíaHita MA. Valores laborales y percepción del estilo de liderazgo en personal de enfermería. Salud Pública Méx. 2007 [cited 2012 Jan 7];49(6). Available from: http://www.scielo.org.mx/scielo .php?pid $=S 003636342007000600006 \&$ script $=$ s ci_arttext. Spanish.

\section{THE AUTHORS}

Ricardo Hodelín Tablada (Corresponding author: rht@medired.scu.sld.cu), neurosurgeon with a master's degree in emergency medicine and a doctorate in medical sciences. Senior researcher and associate professor, Saturnino Lora Clinical-Surgical Teaching Hospital, Santiago de Cuba.
Damaris Fuentes Pelier, ophthalmologist with a master's degree in emergency medicine. Associate researcher, Saturnino Lora Clinical-Surgical Teaching Hospital, Santiago de Cuba.

Submitted: January 7, 2012

Approved for publication: July 16, 2012 Disclosures: None

\section{i. $151 \%$ ACADEMIC PROGRAMS 2013-2014}

Cuba's National School of Public Health (ENSAP) is a regional reference center with faculty recognized internationally for excellence in teaching, research and practice. Its mission is to create human resources for health through postgraduate training in public health specialties, and to strengthen the scientific bases of Cuba's health programs, policy and practice.

ENSAP offers scientific and technical consulting services and develops research programs for health systems and services, as well as academic exchange projects with national and international institutions.

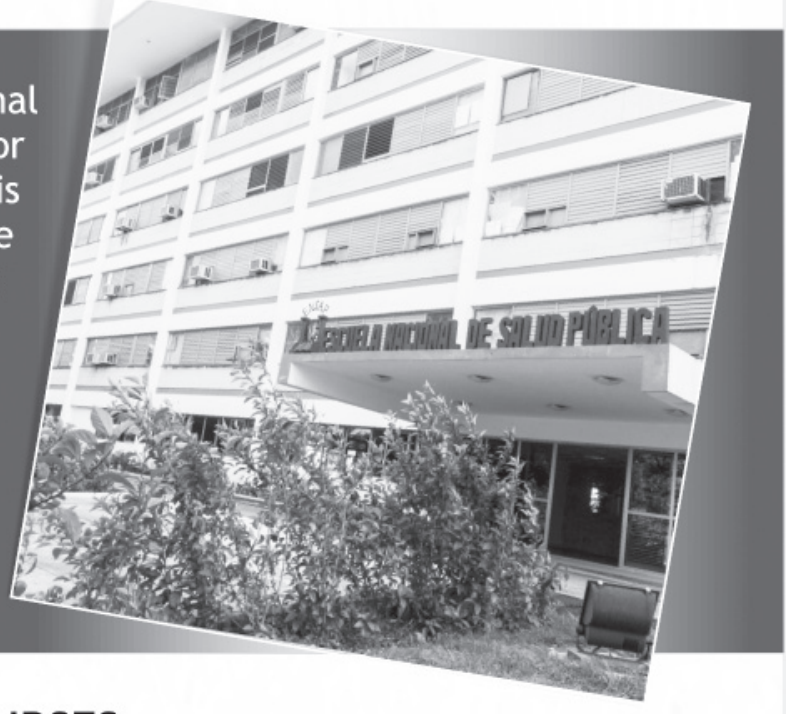

\section{MPH}

- Public Health

- Health Promotion

- Health Psychology

- Primary Health Care

- Health Economics

- Pharmacoepidemiology

\section{PHD}

\section{GRADUATE DIPLOMAS}

- Reproductive Health

- Management in Public Health and Epidemiology

- Health Promotion

- Nursing and Mental Health

- Community Nursing

\section{SHORT COURSES}

- Primary Health Care and Family Medicine in Cuba

- Public Health in Cuba

- Management of Hospital Services in Cuba

- Health Services Management in Primary Health Care in Cuba

- Health Surveillance

- Community Nursing

- Maternal-and-Child Nursing

- Cuban Experiences in Health Promotion

- Health and Quality of Life in Older Adults

- Gender and Health

- Community Participation and Health Equity

- Health and Environment

\section{Contact: info@ensap.sld.cu - www.ensap.sld.cu}

